Agr. Biol. Chem., 38 (10), 1947 1953, 1974

\title{
Extraction of Wheat Flour Proteins with Sodium Dodecyl Sulfate and Their Molecular Weight Distribution
}

\author{
Gen-ichi Danno, Kazuki Kanazawa and Masato Natake \\ Department of Agricultural Chemistry, Faculty of Agriculture, \\ Kobe University, Nada-ku, Kobe, Japan \\ Received May 14, 1974
}

\begin{abstract}
By extraction of wheat flour with sodium dodecyl sulfate (SDS) solution at $\mathrm{pH} 6.8$, about $76 \%$ of the total flour nitrogen solubilized into clear supernatant. This solvent was more effective for extraction of wheat protein than $0.01 \mathrm{~m}$ acetic acid, aluminium lactate-lactic acid buffer ( $\mathrm{pH} 3.1$ ), AUC-solvent $(0.1 \mathrm{~m}$ acetic acid, $3 \mathrm{~m}$ urea and $0.01 \mathrm{~m}$ cetyltrimethylammonium bromide) and 3,5-diiodosalicylic acid lithium salt etc. The molecular weight distribution of the SDS-soluble proteins was studied by SDS-polyacrylamide gel electrophoresis and by molecular sieve chromatography on controlled pore glass (CPG-10-500) without prior reduction of disulfide linkages of the proteins. Most of the SDS-soluble proteins had molecular weight of less than 75,000 , suggesting single-chained proteins. A small amount of relatively high molecular weight proteins which contained intermolecular disulfide linkages was also detected in the gel of electrophoresis, while high molecular weight protein which did not migrate into gel matrix during electrophoresis without prior reduction of disulfide linkages existed in trace amount in the SDS-soluble fraction.

The SDS-insoluble proteins were almost completely extracted by further extraction with SDS in combination with 2-mercaptoethanol or with mercuric chloride.
\end{abstract}

Wheat gluten, which is related to flour's rheological and baking properties, is fractionated into gliadin, which is soluble in neutral $70 \%$ ethanol, and glutenin, which does not dissolve in it. ${ }^{1)}$ Gliadin consists of many different single chained proteins of molecular weight of 16,000 to 50,000 , whose conformations are stabilized by intramolecular disulfide linkages., ${ }^{2,3}$ Glutenin, on the other hand, consists of high molecular weight proteins formed through intermolecular disulfide linkages. ${ }^{4,5}$,

The ratio of gliadin to glutenin, however, varied according to the fractionation methods. Half of acetic acid-soluble gluten was precipitated with $70 \%$ ethanol as glutenin fraction and resulting supernatant was gliadin. ${ }^{7,8)}$ However, by the Maes continuous-extraction process, $40 \%$ isopropanol soluble materials (gliadin) extracted from flour was $50 \%$ or more of the total flour proteins, but $3.85 \%$ lactic acid-soluble materials (glutenin) was only $7 \sim$ $8 \%$ of the total flour proteins..$^{9,10)}$ Proteins, which were extracted with $95 \%$ recovery from wheat flour with mixture of phenol-acetic acid- water $(1: 1: 1, w / v / v)$, had a average molecular weights ranging 14,000 to $52,000{ }^{11}$ ) Most of proteins extracted exhaustively with $2 \mathrm{M}$ urea were reported to be gliadin. ${ }^{12)}$ In addition, there are many reports on sulfhydryl-disulfide interchange during dough mixing., ${ }^{13\rangle}$

These facts arouse a question in our mind whether most of glutenin in gluten is an artifacts produced during dough mixing or during extraction and fractionation procedures. In order to gain some information on this regard, in this study, we used sodium dodecyl sulfate (SDS), which dissociated proteins into the consisted polypeptide chains, as solvent for extraction of the proteins from the wheat flour, and investigated molecular weight distribution of the SDS-soluble proteins.

\section{MATERIALS AND METHODS}

Materials. All of wheat flours used were supplied by Nihon Seifun Co., Kobe. Wheat flour, which was experimentally milled to $60 \%$ extraction from Canada western wheat (No. 1, Canada), was used in this study, except for otherwise noted. Flours from hard red 
winter wheat (U.S.A) and western white wheat (U.S.A.), and commercially milled flours (strong flour, medium flour, and weak flour) were also used to compare with the above flour. Wheat flour was defatted by several extraction with dry $n$-butanol and was then air-dried. Sodium dodecyl sulfate (SDS, special prepared reagent, $99 \%$ ) and 2-mercaptoethanol (special prepared reagent) were purchased from Nakarai Chemicals, Co. Ltd. (Kyoto) and used without further purification. All other reagents were either of guaranteed reagent or of the best grade available.

Extraction of proteins. Defatted wheat flour $(1.5 \mathrm{~g})$ was weighed directly in a 50-ml centrifuge tube and $30 \mathrm{ml}$ of a solvent was added. The suspension was gently stirred for $60 \mathrm{~min}$ at room temperature and the resulting slurry was centrifuged at $11,000 \mathrm{rpm}$ for $30 \mathrm{~min}$ at $5^{\circ} \mathrm{C}$, and the clear supernatant was collected.

For chromatography on controlled-pore glass and SDS-polyacrylamide gel electrophoresis, the extracts were dialyzed against $0.1 \mathrm{M}$ phosphate buffer $(\mathrm{pH} 6.8)$ containing $0.1 \%$ SDS for a day at room temperature and then were concentrated by ultrafiltration using collogion bag (Sartorius-Membranfilter $\mathrm{GmbH}$, Germany). Nitrogen loss under these operation was less than $5 \%$, and most parts of nitrogen lost was nonprotein nitrogen.

Nitrogen was determined by macro and micro Kjeldahl method.

Chromatography on controlled-pore glass. Controlled-pore glass (CPG-10-500, 200/400 mesh, Electronucleonics, Inc.) was equilibrated in a column of $1.6 \times$ $68 \mathrm{~cm}$ with $0.1 \mathrm{M}$ phosphate buffer $(\mathrm{pH} 6.8)$ containing $0.1 \%$ SDS and $0.002 \%$ sodium azide. One $\mathrm{ml}$ of the protein solution was applied to the column. The elution was carried out at $30^{\circ} \mathrm{C}$ with the same buffer. The flow rate was $10 \mathrm{ml}$ per $\mathrm{hr}$ and the effluent was collected in $2 \mathrm{ml}$ portions. The protein concentration of the effluent was measured at $280 \mathrm{~nm}$.

SDS-polyacrylamide gel electrophoresis. SDS-gel electrophoresis was carried out according to the method of Shapiro et al., ${ }^{141}$ modified by Weber and Osborn, ${ }^{151}$ for the determination of molecular weight distribution of the wheat flour proteins. Bovine serum albumin, catalase, aldolase and lysozyme were used as molecular weight standards. The concentration of acrylamide in the separating gel was $5 \%$, and electrophoresis was carried out at $7 \mathrm{~mA}$ per gel $(5 \times 100 \mathrm{~nm})$ for $c a .4 \mathrm{hr}$ at $15^{\circ} \mathrm{C}$. Bromophenol blue was used as an internal standard. Samples extracted from wheat flour and effluent from the column were used for electrophoresis with or without prior reduction with 2-mercaptoethanol. The gels were fixed in 10\% trichloroacetic acid (TCA) for $24 \mathrm{hr}$ and stained with $0.025 \%$ Coomassie brilliant blue R-250 in 10\% TCA for at least $20 \mathrm{hr}$, then des- tained with $10 \%$ TCA. The amounts of proteins were estimated with scanning at $570 \mathrm{~nm}$ by using Ozuma densitometer (Type OZ-82).

\section{RESULTS AND DISCUSSION}

\section{Extraction of flour with various solvent}

Flour from Canada western wheat was subjected to extraction by various solvents, with 1: 30 of flour: solvent ratio, under gentle stirring for $60 \mathrm{~min}$ at $25^{\circ} \mathrm{C}$, and the amount of nitrogen extracted was determined. As shown in Table I, sodium dodecyl sulfate (SDS) was

Table I. Extraction of Nitrogen from Wheat FLOUR WITH VARIOUS SOLVENTS ${ }^{a}$ )

\begin{tabular}{lrr}
\hline \multirow{2}{*}{ Solvent } & \multicolumn{2}{c}{ Nitrogen extracted ${ }^{b)}$} \\
\cline { 2 - 3 } & (mg/g-flour) & $(\%)$ \\
\hline 1.0\% SDS, 0.05 M phosphate & & \\
$\quad$ (pH 6.8) & 17.7 & 75 \\
1.0\% Sodium chloride & 3.4 & 14 \\
0.01 M Formic acid & 15.1 & 64 \\
0.01 M Acetic acid & 14.6 & 62 \\
0.01 M Propionic acid & 14.2 & 60 \\
0.01 M $n$-Butyric acid & 14.2 & 60 \\
0.01 M $n$-Valeric acid & 14.2 & 60 \\
70\% Ethanol, 0.1 M acetic acid & 15.0 & 64 \\
70\% Ethanol & 14.6 & 62 \\
Al-lactate-lactic acid (pH 3.1) & 15.5 & 66 \\
0.1 M 3,5-Diiodosalicylic acid & & \\
lithium salt & 15.5 & 66 \\
AUC-solvent ${ }^{c)}$ & 17.0 & 72 \\
\hline
\end{tabular}

a) Flour: solvent ratio, 1:30, Canada western wheat flour was used.

b) Total flour nitrogen, $23.6 \mathrm{mg} / \mathrm{g}$-flour.

-) $0.1 \mathrm{M}$ Acetic acid-3 $\mathrm{M}$ urea-0.01 $\mathrm{M}$ cetyltrimethylammonium bromide.

the best reagent for extraction of the wheat flour nitrogen, and about $76 \%$ of the total flour nitrogen was extracted with $1 \%$ SDS. This value was somewhat higher than the values obtained with $0.01 \mathrm{M}$ acetic acid, other organic acids, aluminium lactate-lactic acid buffer $(\mathrm{pH}$ 3.1 ), $70 \%$ ethanol, and AUC-solvent ( $0.1 \mathrm{M}$ acetic acid, $3 \mathrm{M}$ urea and $0.01 \mathrm{M}$ cetyltrimethylammonium bromide). 3,5-Diiodosalicylic acid lithium salt, which was a good solvent for membrane proteins, removed only $66 \%$ of 
the flour nitrogen.

\section{Extraction of flour with SDS}

Wheat flour was extracted by varing concentration of SDS and flour: solvent ratio, and nitrogen in the clear solution obtained was determined. As shown in Table II, varing

Table II. EFfect of Concentration of SDS aNd Flour: Solvent Ratio on the ExtractaBILITy OF Wheat Flour Nitrogen ${ }^{a}$ )

\begin{tabular}{ccc}
\hline $\begin{array}{c}\text { Concentration of } \\
\text { SDS }(\%)\end{array}$ & $\begin{array}{c}\text { Flour: solvent ratio } \\
\text { (ml/g-flour) }\end{array}$ & $\begin{array}{c}\text { Nitrogen } \\
\text { extracted }(\%)\end{array}$ \\
\hline 2.0 & 20 & 74 \\
1.0 & 20 & 75 \\
0.75 & 20 & 76 \\
0.5 & 20 & 77 \\
0.25 & 20 & 48 \\
0.25 & $20+20$ & 78 \\
0.1 & 20 & 34 \\
0.1 & $20+20$ & 77 \\
0.5 & 30 & 78 \\
0.5 & 40 & 78 \\
0.5 & 60 & 79 \\
\hline
\end{tabular}

a) Canada western wheat flour was used.

concentration of SDS from 0.5 to $2.0 \%$ had not any significant influence on the extractability of the nitrogen from the flour at 1:20 of flour: solvent ratio. Although extractions with 0.25 and $0.1 \%$ SDS removed only 48 and $34 \%$ of the flour nitrogen respectively, the remaining nitrogen was extracted successively by repeated treatment with the same concentration of SDS. Thus, satisfactory extractability of the nitrogen from the flour was observed when $0.5 \%$ SDS was used at 1:20 of flour solvent ratio.

\section{Molecular weight distribution of SDS-soluble proteins}

Molecular weight distribution of the SDSsoluble proteins from wheat flour were studied by SDS-polyacrylamide gel electrophoresis and by molecular sieve chromatography on controlled pore glass.

A SDS-polyacrylamide gel electrophoretic diagram of nonreduced SDS-soluble proteins is shown in Fig. 1(A). At least 14 bands were observed, although two very adjacent bands

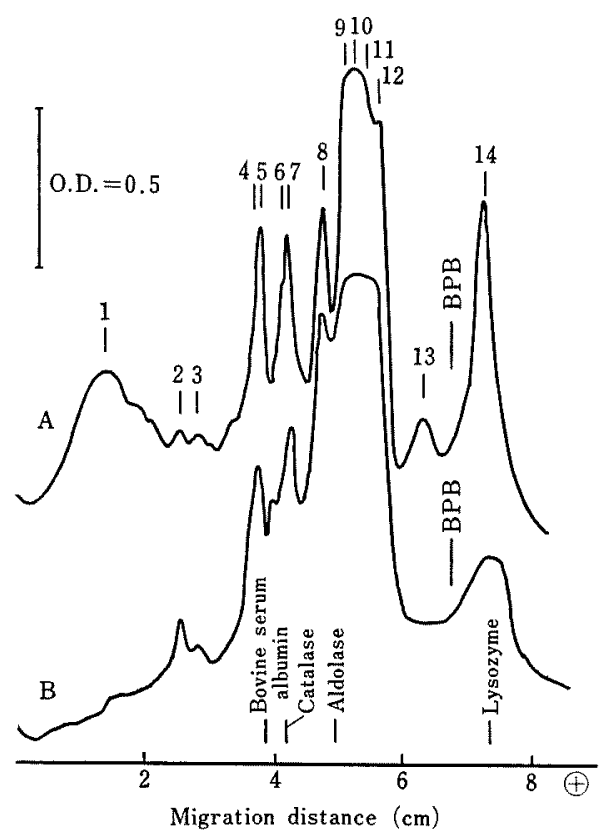

FIG. 1. SDS-polyacrylamide Gel Electrophoretic Patterns of the Proteins Extracted with SDS Solution from Wheat Flour.

Electrophoresis was carried out as described in Materials AND Methods. A. Proteins extracted with SDS from Canada western wheat flour. The sample was submitted to electrophoresis without reduction. B. Proteins extracted with SDS was treated with $1 \%$ 2-mercaptoethanol, overnight at $30{ }^{\circ} \mathrm{C}$. After dialysis against $0.1 \% \mathrm{SDS}$, containing $0.1 \%$ 2-mercaptoethanol, the sample was submitted to electrophoresis.

were represented as a single peak in the densitometric trace. The most intense bands(band 9 to 12) in nonreduced SDS-soluble proteins correspond to a polypeptide of molecular weight 30,000 to 35,000 . The faint, broad bands (band 1) were observed in higher molecular weight region, and trace amounts of material did not enter to the gel during electrophoresis.

It has been shown by Fish et al. ${ }^{16)}$ that gel electrophoresis of nonreduced protein in SDS solution cannot be used to obtain accurate estimates of molecular weight. Therefore, the SDS-soluble proteins sample was incubated with $1 \% 2$-mercaptoethanol overnight at $30^{\circ} \mathrm{C}$ before being applied to the gels. No significant differences in the patterns or in the mobilities of the major bands (band 4 to 12) were ob- 
served between the reduced proteins and the nonreduced ones [Fig. 1(B)]. However, decrease in the amount of the minor bands (band 1) and increase in the band 8 were noticeable. These results indicate that the most of the SDS-soluble proteins had lower molecular weight (less than 75,000) and no intermolecular disulfide linkages, i.e., they are gliadin-type proteins.

SDS-soluble proteins were applied to a controlled pore glass, CPG-10-500 column (1.6× $68 \mathrm{~cm}$ ) equilibrated with $0.05 \mathrm{M}$ phosphate buffer (pH 6.8) containing $0.1 \%$ SDS. The column was developed with the same buffer. The recovery of optical density at $280 \mathrm{~nm}$ was higher than $96 \%$. Two peaks were observed as shown in Fig. 2. Elution volume of main

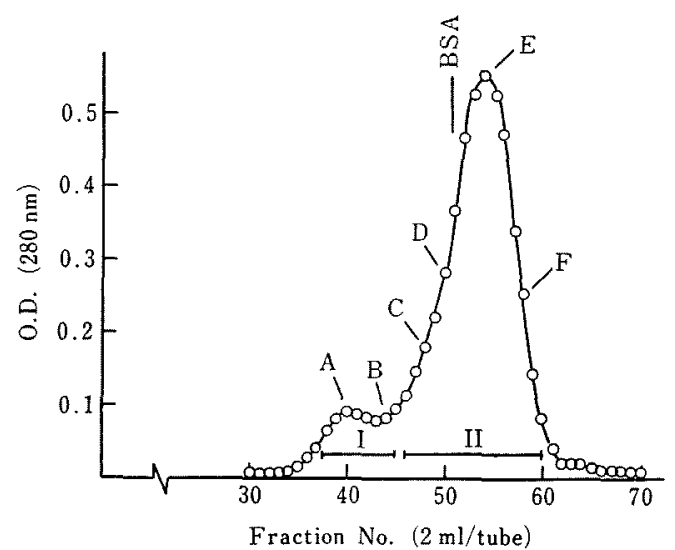

FIG. 2. Molecular Sieve Chromatography on Controlled-Pore Glass (CPG-10-500) Column of the Proteins Extracted with SDS from Canada Western Wheat Flour.

Chromatography was carried out as described in Materials and Methods. Fractions labeled A through $\mathrm{F}$ were subjected to electrophoresis in Fig. 3 . BSA indicates elution volume for reduced bovine serum alubumin. Amount of nitrogen, I, $0.17 \mathrm{mg}$; II, $2.0 \mathrm{mg}$.

peak was larger than that of bovine serum alubumin obtained with the same solvent. Nitrogen contents of main and minor peaks were 2.0 and $0.17 \mathrm{mg}$, respectively. Fractions designated as $A, B, C, D, E$ and $F$ were pooled and were subjected to SDS-polyacrylamide gel electrophoresis. The electrophoretic patterns of each of the fractions are shown in Fig. 3.

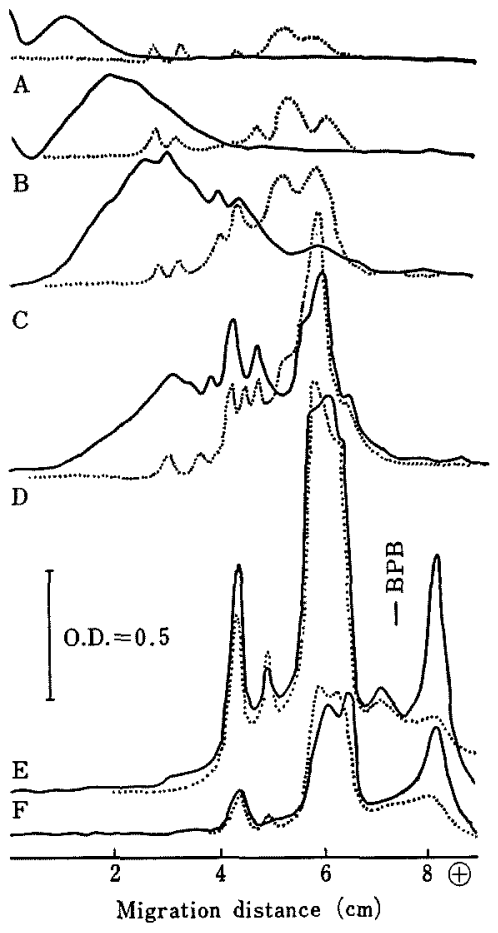

FIG. 3. SDS-polyacrylamide Gel Electrophoretic Patterns of the Fractions Obtained from CPG-10-500 Chromatography as Described in Fig. 2.

The leters correspond to those designated in Fig. 2. Electrophoresis was carried out as described in Materials ANd Methods.

$\longrightarrow$, nonreduced sample; ------, sample reduced with $1 \%$ 2-mercaptoethanol.

Every fractions contained several proteins. Components of main peak (fraction E) were proteins consisted mainly of single polypeptide chain, because their reductive cleavage caused little or no change in molecular weight. Although proteins in minor peak were relatively high-molecular weight proteins which contained intermolecular disulfide linkages, the high-molecular weight proteins which did not enter to the gel during electrophoresis existed only in trace amount. It is well known that pure form of glutenin does not enter to the gel during electrophoresis without cleavage of disulfide linkages. ${ }^{17,18}$ ) Therefore, it is clear that the SDS-soluble proteins extracted from wheat flour did not contain appreciable amounts of high-molecular weight glutenintype proteins.

SDS has been reported to have marked dis- 
sociating power for proteins, and to dissociate many proteins organized through noncovalent bonds into their constituted subunits. Fish et $a l .{ }^{16)}$ showed the sulfhydryl groups on the polypeptide chain in the SDS complex were protected both from the surrounding medium and from each other. Therefore, it can be considered that higher extractability of the wheat flour proteins with SDS and lower molecular weight distribution of the SDSsoluble proteins are due to the obstruction to polymerization through sulf hydryl-disulfide interchange reaction during extraction process with SDS solution.

Extraction of nitrogen with $0.5 \%$ SDS from other five kinds of flours was examined in addition to Canada western wheat flour, and SDS-polyacrylamide gel electrophoresis was conducted for each of the extracts. The results obtained are shown in Table III and Fig. 4,

TAble III. EXtraction of Nitrogen from WheAT FLOUR WITH $0.5 \%$ SDS

\begin{tabular}{lcc}
\hline \multicolumn{1}{c}{ Flour } & $\begin{array}{c}\text { Total } \\
\text { nitrogen } \\
\text { (mg/g-flour) }\end{array}$ & $\begin{array}{c}\text { Nitrogen } \\
\text { extracted } \\
(\%)\end{array}$ \\
\hline Canada western wheat flour $^{a)}$ & 23.2 & 78 \\
Hard red winter wheat flour $^{a)}$ & 22.5 & 76 \\
Western white wheat flour $^{a)}$ & 16.0 & 75 \\
Commercial flour, strong $_{\text {Commercial flour, medium }}$ & 22.4 & 76 \\
Commercial flour, weak & 14.4 & 77 \\
\hline
\end{tabular}

a) Experimentally milled flour, $60 \%$ extracted.

respectively. Over a wide range of flour nitrogen content and baking quality, the amount of SDS-soluble nitrogen on a toal nitrogen basis was relatively constant. Furthermore, no obvious characteristic difference in SDS-polyacrylamide gel electrophoretic patterns were also observed for all flour tested.

\section{Effect of reducing reagent}

Effect of reducing reagent on the extraction of flour nitrogen with $0.5 \%$ SDS was examined. As shown in Table IV, extraction of flour (Canada western wheat) with $0.5 \%$ SDS containing $0.005 \mathrm{M} \quad$ 2-mercaptoethanol removed

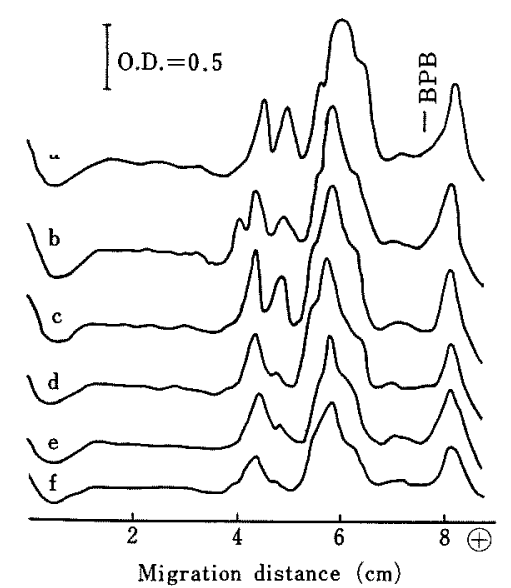

FIG. 4. SDS-polyacrylamide Gel Electrophoretic Patterns of the Proteins Extracted with SDS from Various Flours.

Electrophoresis was carried out as described in MAterials AND Methods. a, Canada western wheat flour; b, Hard red winter wheat flour; $c$, commercial flour, strong; d, commercial flour, medium; e, Western white wheat flour; f, commercial flour, weak.

Table IV. Effect of Reducing Reagent on THE EXTRaction OF Wheat Flour NitrogeN WITH $0.5 \% \operatorname{SDS}^{a\}}$

\begin{tabular}{lcr}
\hline \multirow{2}{*}{ Reagent } & \multicolumn{2}{c}{ Nitrogen extracted } \\
\cline { 2 - 3 } & $(\mathrm{mg} / \mathrm{g}$-flour $)$ & $(\%)$ \\
\hline No addition & 18.1 & 76 \\
$0.005 \mathrm{M} 2-\mathrm{ME}^{(b)}$ & 23.5 & 99 \\
$0.001 \mathrm{M} 2-\mathrm{ME}^{b)}$ & 18.0 & 76 \\
$0.01 \mathrm{M} \mathrm{Na} \mathrm{SO}_{3}$ & 23.6 & 100 \\
Residue $^{()}$ & 5.1 & \\
Residue $^{()}+2-\mathrm{ME}^{b)}$ & 5.0 & \\
\hline
\end{tabular}

a) Canada western wheat flour was used.

b) 2-Mercaptoethanol.

c) Residue after exhaustible extraction with $0.5 \%$ SDS solution.

$99 \%$ of the total nitrogen, and only a starch residue appeared to remain. Nitrogen, which remained in the starch residue after extraction with $0.5 \%$ SDS without reducing reagent, was recovered almost completely by subsequent stirring for $60 \mathrm{~min}$ at $30^{\circ} \mathrm{C}$ with $0.005 \mathrm{M} \mathrm{2-}$ mercaptoethanol. Similar results were obtained when $0.1 \mathrm{M}$ sodium sulfite was added to $0.5 \%$ SDS extractant. These results suggest that the SDS-insoluble components may be 
high molecular weight protein polymerized through intermolecular disulfide linkages.

\section{Effect of sulfhydryl blocking reagent}

To elucidate whether the intermolecular disulfide linkages are formed during the extraction with SDS, sulfhydryl-blocking reagents are added to the SDS solution. Table V

TABLE V. EFFECT OF SUlFHYDRYL-BLOCKING Reagent ON THE Extractablitty of Flour Nitrogen DURING THE EXTRACTION WITH $0.5 \%$ SDS

\begin{tabular}{|c|c|c|}
\hline Reagent & $\begin{array}{c}\text { Flour: solvent } \\
\text { ratioo) } \\
\text { (ml/g-flour) }\end{array}$ & $\begin{array}{c}\text { Nitrogen } \\
\text { extracted } \\
(\%)\end{array}$ \\
\hline No addition & 20 & 75 \\
\hline $\mathrm{HgCl}_{2}\left(10^{-3} \mathrm{M}\right)$ & 20 & 96 \\
\hline $\mathrm{HgCl}_{2}\left(10^{-3} \mathrm{M}\right)$ & $20+20$ & 98 \\
\hline Residue ${ }^{\text {) }}$ & & 2 \\
\hline $\mathrm{HgCl}_{2}\left(10^{-4} \mathrm{M}\right)$ & 20 & 76 \\
\hline $\mathrm{AgNO}_{3}\left(10^{-3} \mathrm{M}\right)$ & 20 & 85 \\
\hline $\left.\mathrm{PCMB}^{b}\right) \quad\left(10^{-3} \mathrm{M}\right)$ & 20 & 76 \\
\hline N-Ethylmaleimide $\left(10^{-2} \mathrm{M}\right)$ & 20 & 76 \\
\hline Monoiodoacetate $\left(10^{-2} \mathrm{M}\right)$ & 20 & 76 \\
\hline $\begin{array}{l}\text { Residue after exhaus } \\
\text { SDS solution contain } \\
\text { b) p-Chloromercuribenze } \\
\text { c) Canada western whea }\end{array}$ & $\begin{array}{l}\text { ible extraction } \\
\text { ng } 10^{-3} \mathrm{M} \mathrm{HgCl} \\
\text { ate. } \\
\text { flour was used. }\end{array}$ & with $0.5 \%$ \\
\hline
\end{tabular}

shows effects of sulfhydryl-blocking reagents added to $0.5 \%$ SDS on the amount of nitrogen extracted from flour. When mercuric chloride was added to give a final concentration of $10^{-3}$ $\mathrm{M}$ to the $0.5 \% \mathrm{SDS}$ solution containing flour at 1: 20 of flour: solvent ratio, then the systems were stirred gently for $60 \mathrm{~min}$ at $30^{\circ} \mathrm{C}, 96 \sim 98$ $\%$ of the total flour nitrogen was recovered and only $2 \%$ of the nitrogen remained in the starch residue, though no effect was observed at concentration below $10^{-4} \mathrm{M}$ of mercuric chloride. The amount of nitrogen extracted from flour was also increased by addition of $10^{-3} \mathrm{M}$ silver nitrate. But addition of other sulf hydrylblocking reagents, such as $p$-chloromercuribenzoate, $\mathrm{N}$-ethylmaleimide and monoiodoacetate, to $0.5 \%$ SDS solution were not effective for the extractability of nitrogen from wheat flour under the condition described above.
Existence of high molecular weight proteins in flour

As shown in Fig. 5, the amount of nitrogen solubilized with $0.5 \%$ SDS solution $(\mathrm{pH} 6.8)$

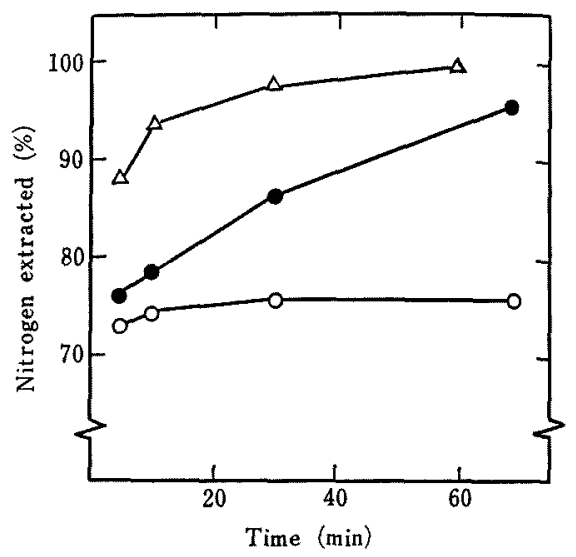

FIG. 5. Time Course of Extraction of Wheat Flour Nitrogen with SDS solution.

$0-0,0.5 \%$ SDS (pH 6.8) only; - $0.5 \%$ SDS + $10^{-3} \mathrm{M} \quad \mathrm{HgCl}_{2} ; \triangle-\triangle, 0.5 \% \mathrm{SDS}+5 \times 10^{-3} \mathrm{M} 2$. mercaptoethanol.

Canada western wheat flour was used.

reached to possible maximum yield within 10 min. Addition of $10^{-3} \mathrm{M}$ mercuric chloride in extraction with $0.5 \%$ SDS led to gradual increase of the nitrogen extracted, i.e., 80, 92 and $98 \%$ of the total flour nitrogen were removed in 10,30 and $70 \mathrm{~min}$, respectively. The similar result was observed when 2-mercaptoethanol was added into $0.5 \%$ SDS solution. Furthermore, most of the nitrogen, which remained in the starch residue after extraction with $0.5 \%$ SDS solution, could be also extracted by gentle stirring for $5 \mathrm{hr}$ at $30^{\circ} \mathrm{C}$ with $10^{-3} \mathrm{M}$ mercuric chloride in $0.5 \%$ SDS solution (pH 6.8). From these results, it could be denied that solubilization effect of mercuric chloride was due to preventing the polymerization through sulfhydryl-disulfide interchange during extraction with SDS; if mercuric chloride prevented the polymerization, the time to reach to maximum solubility by using mercuric chloride must have been more shorter, and nitrogen remained in the residue would never been extracted by successive treatment with mercuric chloride. Thus, it appeared clearly 
that the intermolecular disulfide linkages did not occur during the extraction with SDS from wheat flour. Huebner and Rothfus, ${ }^{19}$ and Redman $^{20)}$ recently pointed out the existence of high molecular weight proteins (glutenin) in wheat flour by extraction procedures, and showed that extraction with water followed by $2 \mathrm{~m}$ urea did not remove all protein from wheat flour. On the basis of their results, they contended that glutenin might not be an artifact of extraction. It appears that our results do not incompatible with those of Huebner and Rothfus, and of Redman. However, it should be noted that the SDS extract from wheat flour in the present study contained less highmolecular protein as compared with $2 \mathrm{M}$ urea extracts from flour. ${ }^{19}$ )

Mechanism of the solubilization effect of mercuric chloride will be described elsewhere.

Acknowledgement. The authors wish to express their appreciation to Nihon Seifun Co., for supplying the wheat flours used in this study.

\section{REFERENCES}

1) T.B. Osborne, "The Protein of the Wheat Kernel," Carnegie Institution of Washington Publ., 1907, p. 84 .

2) H. C. Nielsen, A.C. Beckeith and J.S. Wall,
Cereal Chem., 45, 37 (1968).

3) J. H. Woychik, F. R. Huebner and R. J. Dimler, Arch. Biochem. Biophys., 105, 151 (1964).

4) R. W. Jones, G. E. Babcock, N. W. Taylor and F. R. Senti, ibid., 94, 483 (1961).

5) H. C. Nielsen, G. E. Babcock and F. R. Senti, ibid., 96, 252 (1962).

6) Z. Hamauzu and D. Yonezawa, Agr. Biol. Chem., 36, 2421 (1972).

7) R. W. Jones, N. W. Taylor and F. R. Senti, Arch. Biochem. Biophys., 84, 363 (1959).

8) R. C. Hoseney, K. F. Finney, Y. Pomeranz and M. D. Shogren, Cereal Chem., 46, 495 (1969).

9) P. J. Mattern, A. Salem and G. H. Volkmer, ibid., 45, 319 (1968).

10) P. C. Williams and C. Butler, ibid., 47, 626 (1970).

11) P. E. Stanley, A. C. Jennings and D. J. D. Nicholas, Phytochem., 7, 1109 (1968).

12) J. W. Lee, J. Sci. Fd Agr., 19, 153 (1968).

13) K. Tanaka and W. Bushuk, Cereal Chem., 50, 590, 597, 605 (1973).

14) A. L. Shapiro and E. Vinuela, Biochem. Biophys. Res. Commun., 28, 815 (1967).

15) K. Weber and M. Osborn, J. Biol. Chem., 244, 4406 (1969).

16) W. W. Fish, J. A. Reynolds and C. Tanford, ibid., 245, 5166 (1970).

17) J. H. Woychik, J. A. Boundy and R. J. Dimler, Arch. Biochem. Biophys., 94, 477 (1961).

18) R. J. Wasik and N. W. Bushuk, Cereal Chem., 51, 112 (1974).

19) F. R. Huebner and J. A. Rothfus, ibid., 48, 469 (1971).

20) D. G. Redman, Phytochem., 12, 1383 (1974). 